\title{
Alexandra ERdős
}

Langston Hughes, the Unnamed Hero Behind the Civil Rights Movement. W. Jason Miller. Langston Hughes (Critical Lives).

Pro\&Contra 5

No. 1 (2021) 67-72. 

Little is it known that Martin Luther King's famous "I Have a Dream" speech from 1963 was inspired by "I Dream a World," a poem written by Langston Hughes in 1941 and published in 1945. King's famous speech echoes Hughes' words and ideas from 20 years before, and almost exactly mirrors the way the two icons spoke, as if they were contemporaries.

The new biography, as part of the Critical Lives series, aims to present critical figures of culture, literature, and history, in short, and in "the context of their lives." The innovation of the series is that writers also provide readers with illustrations, such as-in the case of Langston Hughes - photographs about himself in various stages of his life (some taken by his friends Henri Cartier-Bresson and Marion Palfi), photographs about his family members, and about handwritten or typed poems — some even containing his signature and/or changes in the words and lines. The series also aims at offering short analyses of major works by the artists, philosophers, or even politicians in question. Miller's book definitely has some freshness compared to the previous biographies written on Langston Hughes. Because of its shortness, it is adequate reading material for the general public and a good starting point for undergraduate students and their theses.

W. Jason Miller (author of Langston Hughes and American Lynching Culture [2011] and Origins of the Dream: Hughes' Poetry and King's Rhetoric [2015]) presents Hughes's life in its most significant events. One of the focal points of book is the people that impacted the writer's life, career, and authorship, and also the people Langston Hughes influenced. Such is Alice Walker, for instance, but the most important among all is Dr. Martin Luther King, Jr., the Civil Rights Movement leader. The stages and intervals presented in the book are further enhanced by significant poems or essays that are also analyzed true to the series' aims. The book also presents how American poets, such as Walt Whitman and Carl Sandburg influenced Hughes's poetry, especially how he used the free verse to speak on behalf of the poor and middle-class black Americans. Miller also reveals that this influence helped Hughes revolutionize blues and jazz poetry into what it is today.

The book consists of eleven chapters, each chapter focusing on certain periods of Hughes's life and the most important events and people from those years. The most interesting for Hughes scholars would be the first chapter with its newly-found information, and the last three in which the reader glimpses into the relationship between the African American Poet Laurate and the Reverend. The first chapter opens with the poet's early life and famous ancestry, something that people unfamiliar with him might not notice at first. Namely, Langston Hughes's birth year is 1901, not 1902 - as believed by the poet and writer, and his biographers. Both Faith Berry and Arnold Rampersad in their respective biographies state 1902 to be Hughes's year of birth. The basis of the new information is found in an article written by Jennifer Schuessler (reporter of culture and intellectual life) for The New York Times in 2008. According to the reporter, Eric McHenry (poet and teacher at 
Washburn University in Topeka, KS) conducted an online search for an ancestor of his from Topeka and came across unknown documents about Hughes's early life, namely evidence about his year of birth. Interestingly, in the early 1900s in the state of Missouri it was not required to document and record birth dates. Readers can rightly ask the question what significance a different year of birth means in the writer's life, and does anything change in regard to Hughes's work and its content? Unfortunately, Jason Miller does not offer an answer to that question, nor is this newly-found information elaborated further-one of the book's few possible flaws.

Further chapters also present some of Langston Hughes's major poems. Some of these are among his earliest ones, "Fairies" (1921) and "Dream" (1923). In these poems one can find the earliest mentions of Hughes's signature metaphor of the dream, which will culminate in the 1951 collection of poetry, Montage of a Dream Deferred. Another important poem discussed is "Mother to Son," published in December 1922, which, according to Miller, became "deeply embedded in the common vernacular of African American culture" (29). The above-mentioned poems paved Hughes's way to become an influential African American poet, writer, essayist, and dramatist. He was concerned with the black experience in America and the African American consciousness. Forty years later his poems and metaphors of the dream inspired Martin Luther King, Jr., and Langston Hughes became the unknown hero and voice behind the Civil Rights Movement.

Regardless of being a Hughes scholar or not, one cannot overlook the fact that Hughes called for a revolutionary civil rights movement years, rather decades, before Martin Luther King Jr. was chosen as the leader of the movement in the 1950s and became its hero in the 1960s. However, this does not change the fact that the two men were inspirations for each other. While Hughes spoke like an artist, King did like a reverend. Even though there was mutual respect between the two men, Martin Luther King Jr. never mentioned Hughes' name in any of his speeches, nor did he indicate who was the "mastermind" behind the ideas that changed the 1960s. One of the possible reasons was Hughes's well-known affiliation with the Left, though the poet never officially entered nor sympathized with any communist party. In the turbulent years around Hughes and his affiliation, topped with the hearing before Joseph McCarthy in 1953 during the Red Scare, Martin Luther King Jr. himself and his Southern Christian Leadership Conference were also accused of being in the communist front. This was the reason why the Reverend distanced himself and his organization, and severed public ties with the African American poet.

Despite being questioned and requested to testify for Communism (if not, at least provide McCarthy with names of communist sympathizers) both men continued to show their respect for the other, and in their own ways, their infinite support. On the one hand, Hughes was so deeply impacted by King's presence and role in the MIA (Montgomery

Pro\&Contra 1 (2021) 67-72. 
Improvement Association) and Southern Christian Leadership Conference that the Reverend became an integral part of Hughes's poetry and journalism. According to Miller, King appeared "as the subject or earn[ed] a key mention in no less than forty articles Hughes wrote for the Chicago Defender" (146). Hughes also declared on two occasions that King would become a "permanent fixture of black history" (Miller 146). On the other hand, the previously mentioned poem, "Mother to Son", was King's first choice to recite in 1956 to honor his wife and celebrate Mother's Day. That same year, which was also one year after the Montgomery Bus Boycott, during which King was chosen to become the leader of the Civil Rights Movement, Langston Hughes wrote the poem "Brotherly Love." This was not only about the Reverend, but also dedicated to him and published in the poet's newspaper column in The Nation. Interestingly, the poem is "narrated" by Simple (who appears by the name Jesse B. Simple, and is Hughes's "most fascinating Negro character" (see Arthur P. Davis) himself instead of a constructed speaker, and it is one of the rare instances in which the prose character fluently transmits the poet's words in a different genre. The same Simple in a 1963 article imagines himself as the president of the United States, and in case he is ever elected his first order will be: "I hereby command the misusers to turn over all dogs, prod rods, and fire hoses to Rev. Martin Luther King” (Miller 149).

The bond between the two African American intellectuals just strengthened as years passed. Jason Miller states: "the connection between these two icons [Hughes and King] demonstrate how Hughes's poetry played as much of a key role in the civil rights movement as it did in shaping the New Negro Movement" (159). Anyone who does a thorough research in both men's works cannot overlook how much Hughes influenced King's sermons and speeches. During their time of acquaintance, Hughes was watched by the HUAC, which led to their silence towards each other, but they never ceased to admire each other. Given these circumstances, it is reasonable why King never invoked Hughes's name publicly nor mentioned it. King was, nevertheless, able to get Hughes's words across to millions of African Americans and for future generations, and, as Miller observes, they "were linked visually as writer and performer" (185). As a conclusion we can state that the new biography indeed "illuminates Hughes's status as an international literary figure," whose contribution to the African American literary canon and to the Civil Rights movement cannot be overlooked. Jason W. Miller makes use of unpublished letters and manuscripts to re-construct the image readers have of Langston Hughes. From "the most beloved African American poet of the twentieth century ${ }^{2}$," Hughes

\footnotetext{
${ }^{1}$ From the abstract found on the back cover.

${ }^{2}$ From the abstract found on the back cover.
} 
is repositioned as a genius writer who encouraged and promoted poets and writers, and inspired generations of activists and politicians, not only Martin Luther King, Jr., but also such individuals as Barack Obama, the first African American president of the United States. 